\title{
Edición e estudo lingüístico do romance de María Francisca de Isla y Losada ao Cura de Fruíme (ca. 1774-1777)*
}

Ramón Mariño Paz

Universidade de Santiago de Compostela

\begin{abstract}
Resumo:
Este artigo contén unha edición do romance que María Francisca de Isla y Losada lle enviou a Diego Antonio Cernadas y Castro entre 1774 e 1777. Alén disto, ofrécese nel un estudo lingüístico da peza, da que pode extraerse importante información sobre o galego oral e escrito do século XVIII.
\end{abstract}

Palabras chave:

Galego Medio, século XVIII, textos poéticos.

\begin{abstract}
:
This article contains an edition of the poem that was sent by María Francisca de Isla y Losada to Diego Antonio Cernadas y Castro between 1774 and 1777. In addition, a linguistic study of this poetic text is offered. Important information on oral and written Galician of the $18^{\text {th }}$ century can be gathered from it.
\end{abstract}

Key words:

Middle Galician, $18^{\text {th }}$ Century, poetical texts.

\section{1. $O$ texto e o seu contexto}

Filla do fidalgo asturiano José Isla Pis de la Torre e da galega María Rosa Losada y Osorio, da tamén fidalga casa de San Lourenzo de Trives, María Francisca de Isla y Losada (1734-1808) naceu e morreu en Santiago de Compostela, onde seu pai exerceu desde 1720 como Rexedor Perpetuo e como Alcalde Maior e Superintendente dos Estados de Altamira en Galicia. Era medio irmá e afillada do

\footnotetext{
* Agradézolle a Ricardo Gutiérrez Pichel as xestións que realizou para a adquisición dunha reprodución fotográfica do manuscrito.
} 
xesuíta José Francisco de Isla, o famoso Padre Isla, que nacera en Asturias en 1703 do primeiro matrimonio de don José Isla. Con el mantivo a poeta compostelá unha estreita relación persoal e intelectual, e mesmo parece que o sonado autor do Fray Gerundio de Campazas lle facía a María Francisca consultas sobre as súas obras e incluso lle admitía correcións, cousa realmente insólita nunha época en que xeralmente se desdeñaba a instrución das mulleres, case sempre relegadas á execución dos rutinarios labores domésticos.

Lonxe, pois, da posibilidade de recibir unha educación regrada e de seguir o tipo de estudos superiores que entón se reservaba para os homes, a insólita formación daquela señorita fidalga da Compostela de mediados do século XVIII sería o feliz froito da conxunción da súa natural intelixencia e a súa persoal inclinación ao saber ${ }^{1}$ coas aprendizaxes que recibiría dos ilustrados ambientes que polas súas relacións familiares frecuentaría desde moi nova. Con estas suxerentes palabras evocou e imaxinou Martínez Barbeito (1958: 25-26) os escenarios en que se produciría a educación de María Francisca:

La amistad de prelados, canónigos y frailes dados al estudio, de catedráticos y colegiales y de militares, funcionarios y aristócratas cultivados, tenía que impregnar el ambiente social de la familia Isla de un tono refinadamente espiritual. Y doña María Francisca, joven, vivaz, curiosa y apasionada, recibió influencias beneficiosas de aquella sociedad señorial y culta. Poetas de poderoso aliento y de armoniosas formas barrocas como don Bernardo Ribera, regidor como su padre, del Municipio compostelano; o caudalosos rimadores como don Diego Cernadas de Castro, cura de Fruíme; juristas como don Melchor Basadre o don Agustín Vales Vaamonde, ambos catedráticos de la Universidad; sabios como don José Cornide o don Antonio Riobóo Seijas Villardefrancos; clérigos ilustrados como don Pedro Antonio Sánchez o don Antonio Páramo, y muchos otros personajes debieron haber sido los que doña María Francisca iba conociendo año tras año en las veladas, entre encopetadas y familiares, de los salones compostelanos, en que se tomaba chocolate, se jugaba a prendas y charadas, se hacía algún experimento de física recreativa y se discutían arduos puntos de erudición o bien la conveniencia y riesgos de tal o cual reforma sobre el cuerpo del país.

Tras a morte do Padre Isla no desterro italiano en 1781, María Francisca traballou arreo para conseguir que se publicase a obra inédita do xesuíta e para que se dese ao prelo o Compendio histórico de la vida, carácter moral y literario del célebre Padre Josef Francisco de Isla, con la noticia analítica de todos sus escritos (Madrid, 1803), unha biografía que, aínda que apareceu atribuída a Josef Ignacio

1 Xa adulta, fala elocuentemente desta súa curiosidade intelectual o feito de que en 1785 Roma lle concedese a licenza para ler libros prohibidos que ela solicitara (cf. Monlau 1850: XVI, n. 1). 
de Salas, probable pseudónimo do Padre Juan José Tolrá, non chegaría a materializarse sen a decisiva intervención da chamada "Perla Gallega" ou "Musa Compostelana", que mesmo pode ser considerada a súa auténtica autora (cf. Serrano y Sanz 1903: I, 536-541; Martínez Barbeito 1958: 29-30). Filgueira Valverde (1984: 72) opina que tamén se lle debe atribuír a ela a breve biografía anónima de Diego Cernadas que encabeza o tomo II das obras completas deste (cf. Cernadas y Castro 1778-1781: II, VIII-XXI), e non me parece desencamiñada tal atribución porque creo que a apoian non soamente os indicios que no seu artigo expón o polígrafo pontevedrés, senón tamén a circunstancia de que quen escribiu esas liñas sobre Cernadas se escusa pola súa tardanza en facelo alegando que "una larga y grave enfermedad que he sufrido, fue la causa de no cumplir antes con el precepto de Vm. y mi deseo de servirle, enviándole, como lo executo ahora, un extracto de la vida de nuestro Cura de Fruime" (in Cernadas y Castro 1778-1781: II, VIII): referencias a esta grave e prolongada doenza hainas tanto no poema que neste traballo se edita e estuda coma na correspondencia que por aqueles anos lle mandou á súa medio irmá o Padre Isla desde Italia (cf. Isla 1850: 525-542)² e incluso nunhas décimas en que o abade de Fruíme lle dicía á súa amiga que "de tu salud trabajosa / la fatal constitucion / me traspasa el corazon" (Cernadas y Castro 17781781: IV, 316). Alén disto, Filgueira Valverde (1984: 73) informa de que na Biblioteca Nacional de Madrid se garda un "Canto Heroico" manuscrito titulado "Despedida de Lidia y Armido" que se compón de cento trinta e cinco oitavas reais e que na súa opinión é tamén da autoría de María Francisca de Isla.

Da súa obra poética en galego só coñecemos hoxe o romance ao cura de Fruíme que deu a coñecer Martínez Barbeito en 1958, sobre o que eu volvo agora neste artigo. Aqueles que nos transmitiron noticias sobre a vida de dona María infórmannos de que foi ela mesma, talvez convencida do seu cativo valor literario, quen pouco antes da súa morte mandou destruír a meirande parte das poesías que compuxera. Algunhas das que se salvaron chegou a lelas Pedro Felipe Monlau (1850: XVI, n. 1), quen as despachou dedeñosamente dicindo delas que consistían "casi todas en cuartetas, décimas y otros poemitas menores sobre asuntos insignificantes" e emitindo a seguir a seguinte sentenza: "á juzgar por lo que hemos visto, si en materias literarias ántes importa ser justos que galantes, dirémos con llaneza que nada absolutamente perdió el Parnaso castellano con haberse entregado al fuego las frias y asaz mal rimadas inspiraciones de la hermana del PADRE ISLA". Destas palabras de Monlau parece deducirse que nese monllo de poemas de María Francisca de Isla que el alcanzou a coñecer non había ningún escrito en galego, xa que o que el afirmaba era que coa destrución dos traballos da Perla Galega o que non perdera nada fora o "Parnaso castellano", sen alusión ningunha ao Parnaso galego. Con todo, carezo de probas que me inclinen a afirmar tal cousa con toda a rotundidade.

2 "Tú te lloras viuda y reducida á una cama casi siempre" (Isla 1850: 529), escribíalle o xesuíta desde Boloña o 18 de abril de 1776. 
Excepcionalmente, o romance dirixido a Diego Antonio Cernadas, abade de Fruíme, chegou ata nós porque se conservou nunha copia del que fixo e gardou o polígrafo José Cornide y Saavedra, con quen María Francisca de Isla mantivo un trato amical que nacería nos seus primeiros encontros en reunións celebradas nos salóns composteláns e que posteriormente se consolidaría coa súa relación epistolar e cos novos contactos que quizais manterían en Madrid, cidade que a Perla Galega visitou e na que mesmo chegou a residir durante algún tempo. Por conseguinte, a versión do poema que actualmente coñecemos non procede dun autógrafo da súa autora, senón dunha copia realizada por Cornide antes do 22 de febreiro de 1803, o día en que faleceu en Madrid. Da data en que o romance se compuxo podemos dicir, repetindo o que xa afirmou Martínez Barbeito (1958: 34), que se ten que situar entre o outono de 1774, cando María Francisca enviuvou do seu marido Nicolás Jacinto de Ayala, e o 30 de marzo de 1777, o día en que Diego Antonio Cernadas y Castro morreu na súa freguesía de Fruíme. Recórdese que no verso 73 do romance a autora se presenta a si mesma como unha "probe viuda".

A composición, evidentemente desprovida de toda grandeza literaria aínda que si dotada dunha estimable riqueza lingüística, insírese no fluxo de correspondencia rimada de ton menor que discorreu entre dona María e Diego Cernadas, da que pode lerse unha simpática mostra no tomo IV das obras completas do abade de Fruíme (Cernadas y Castro 1778-1781: IV, 310-342). Trátase, como atinadamente xulgou Martínez Barbeito (1958: 33), dunha "amable y simpática correspondencia en verso [...] que poco o nada tiene que ver con la poesía” e que podía fluír tanto en galego coma en castelán. Nesas amigables conversas rimadas os dous correspondentes rifábanse risoñamente pola tardanza en contestar a unha carta enviada ou en devolver ou facer unha visita, contábanse mutuamente as doenzas e as penas que os amarguraban ou ponderaban as virtudes dos regalos (tabaco, chocolate, turrón, castañas, candeas para a Virxe das Dores de Fruíme, etc.) con que a dama de Compostela adoitaba agasallar o seu amigo, aquel "Desdentado Vegete" (Cernadas y Castro 1778-1781: IV, 333) que retranqueiramente dicía estrañarse de "que los diezmos me pagues, / si mi feligresa no eres" (Cernadas y Castro 17781781: IV, 330). Certamente, este tipo de composicións estaba en plena sintonía co esquema sociolingüístico imperante na Galicia da época, que lles reservaba ao latín e ao castelán as funcións da creación e a transmisión do coñecemento e da literatura "seria", en tanto que ao galego, concibido pola gran maioría como un dialecto, lle asignaba usos culturais considerados menores que tamén se podían executar en castelán, como podían ser, entre outros, os da elaboración de poemas e escritos xeralmente breves e de escasa ambición intelectual e estética (cf. Mariño Paz 2000: 58-61). 
O romance en galego de María Francisca de Isla encóntrase nun manuscrito depositado na Real Academia da Historia (Madrid) que leva a signatura 9-3894, $\mathrm{n}^{\circ} 35$ (anteriormente tiña a 11-2-7-417, que é a que dá Martínez Barbeito). Forma parte do legado que José Cornide lle deixou despois da súa morte á institución académica madrileña, da que fora nomeado secretario perpetuo o ano 1802. Escrito con certeza pola man do ilustrado galego, ocupa as catro caras dun primeiro bifolio (1a, $1 \mathrm{~b}, 1 \mathrm{c}, 1 \mathrm{~d})$ e as dúas primeiras doutro $(2 \mathrm{a}, 2 \mathrm{~b})$. Está acompañado dunha folla que contén a copia incompleta da cantiga de Santa María en que se conta como a Virxe salvou a raíña Beatriz, esposa de Fernando III o Santo, dunha grande enfermidade (é a número 256 do códice E e tamén da edición de Mettmann 1959-1972); a esta copia, que presenta a mesma letra ca a do romance de Isla y Losada e se estende ao longo das dúas caras da folla en que foi escrita, fáltanlle a primeira estrofa e a primeira metade da segunda ${ }^{3}$. As dúas composicións van dentro dun caderniño que na súa portada di "En dialecto gallego". No mesmo volume do legado de Cornide, o caderno inmediatamente anterior a este (o no 34) contén "Poesias castellanas de D. Josef Cornide y otros". En definitiva, podemos dicir que nos atopamos ante unha pequena mostra das afeccións poéticas do ilustrado coruñés, que polo seu traballo en arquivos pertencía á minoría que tiña coñecemento das Cantigas de Santa María antes de que a noticia da súa existencia comezase a ser propalada durante o Rexurdimento.

Dado que a edición que aquí presento se destina exclusivamente á realización dunha análise lingüística, decidín facer unha transcrición completamente respectuosa da literalidade do orixinal, sen intervir en aspectos tales como o desenvolvemento de abreviaturas, a unión e separación de palabras, o uso das letras maiúsculas, a acentuación e a puntuación. A edición así elaborada non entorpece a lectura comprensiva do romance e, proporcionando todas as garantías esixibles para a realización do estudo lingüístico, poderase constituír en base de partida para posibles futuras edicións concibidas para o cumprimento de fins diferentes dos que eu me propuxen e executadas con outros criterios.

De as haber, despois de cada cuarteta indico as particularidades do manuscrito que me parecen dignas de mención e, cando o estime pertinente, tamén as variantes que ofrece a lectura de Carlos Martínez Barbeito (MB), prescindindo de todo aquilo que foi intervención consciente do polígrafo coruñés nos aspectos que mencionei anteriormente: desenvolvemento de abreviaturas, unión e separación de palabras, uso de maiúsculas, acentuación e puntuación. Esporadicamente anotei tamén algunhas achegas da edición de Álvarez Blázquez (1959: II, 304-306) (AB), xa que este investigador consultou o manuscrito da Real Academia da Historia e o seu traballo presenta algunhas particularidades que considero dignas de atención. En tro-

3 A súa transcrición ofrécese como apéndice ao final deste artigo. 
ques, pareceume innecesario recompilar as variantes de lectura doutras edicións divulgativas que se realizaron posteriormente partindo da de Martínez Barbeito ou da de Xosé María Álvarez Blázquez. Entre ángulos sinalo o inicio de cada unha das caras dos dous bifolios en que está copiado o poema.

Esta é, pois, a miña edición: 


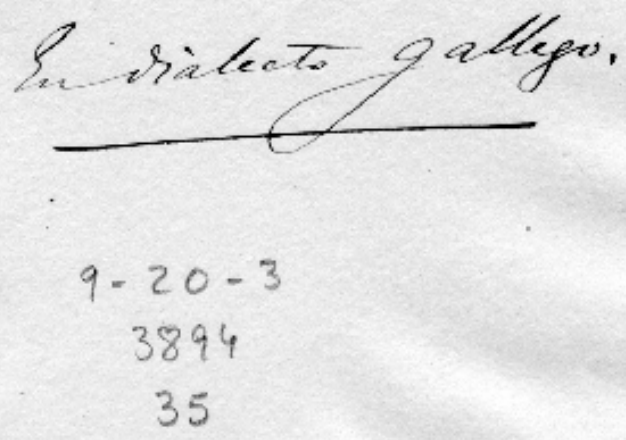


Ramón Mariño Paz

Revista de a filoloxía

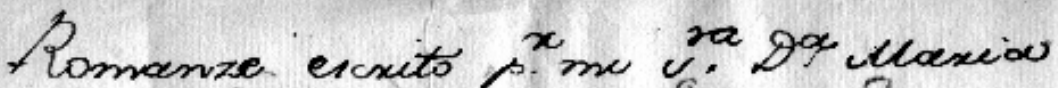
Ota ca de viay donada ib

$8^{\circ}$

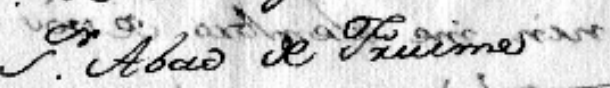

Ou mex Cxesp? veing gures,

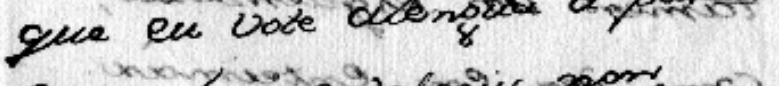
Cowar beni, e defpoiv araranco

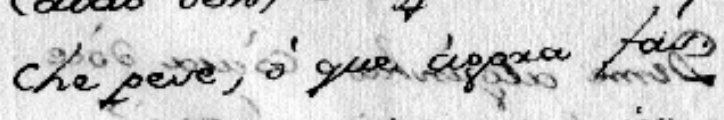
Centras tota comencia e contrea tada com taim mall.

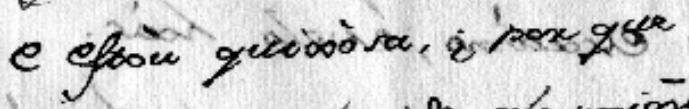

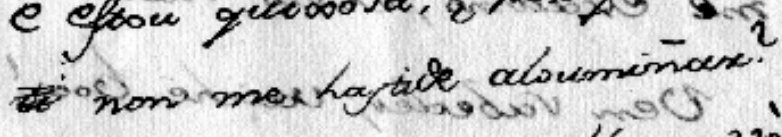
Seigue hei per que alón nom valwa ávéritor der Dolanaxan? aind

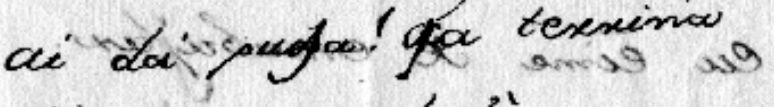
érós eporan cubisiáx.

tr qua me tratachy be' '́ Dociriza man papas $x$ wark andos vaxtwo

$\overline{64}$ 
$<1 \mathrm{a}>$

Romanze escrito $\mathrm{p} .{ }^{\mathrm{r}}$ mi $\mathrm{S}^{\mathrm{ra}}$. $\mathrm{D}^{\mathrm{a}}$ Maria

Fran $^{\text {ca }}$. de Ysla y Losada al

$\mathrm{S}^{\text {or }}$. Abad de Fruime

Ôu mèu Crego? Sei q' qués,

que eu vote alengua â paseàr?

Catao ben, e despois non

che pese, ò que agora fás.

1 Entre Sei e q' hai unha letra riscada que non se le.

Se contra toda concencia

pensache de min tàn màl, e estòu quixòsa, ¿por que

non me hastide aloumiñar?

7 AB queixosa. 8 Antes de non, lese $t i$ riscado.

Seique hè por que aló non vòlva

ávèrbos de Balandran?

ai dá puja! q'a terriña

12 évòs para cubizár.

11 Lese puxa corrixido para puja. 12 Lese ébòs corrixido para évòs; o $<\mathrm{r}>$ de cubizar leva un til grave por riba.

An que me trataches bén

s' àvesita non pagàs 
Ramón Mariño Paz

Revista de a filoloxía

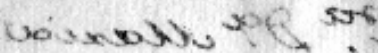

Qoec sỉems pè dela poño

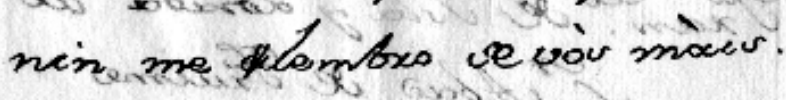

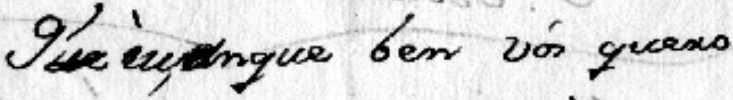

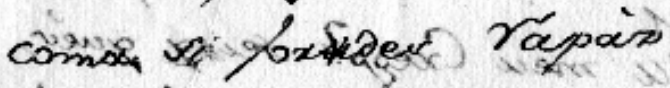
Famiens vor enguenzexei, como dea ex enteimaix.

Dime algiontio ciugser joje como Labai docta, éfató, 1 i a que $S$ uni nono fag icedor, me excotiono, évels hair s' coms entow cownew taing - madia tender, Aenassious ex eime te entoubrijors.

arpeito, poto que vj\% at?

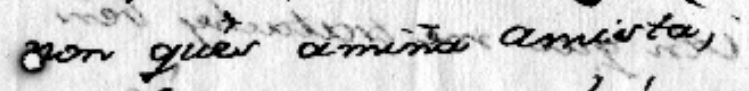
far benis macia ercomanć outiar combicla nax achaj,

$\overline{66}$ 


$<1 \mathrm{~b}>\quad \begin{aligned} & \text { dou ò Demo pè ala poño } \\ & \text { nin me lembro de vòs màis. }\end{aligned}$
14 Debaixo do apóstrofo
non se recoñece. 16 Lese $\quad \begin{aligned} & \text { Q' èu, anque ben vós quero } \\ & \text { coma si fordes rapàz } \\ & \text { tamen vos esquenzerei, } \\ & \text { como dea en enteimàr. }\end{aligned}$

17 Lese Que corrixido para $Q^{\prime} .18$ Lese for 1 des, co <a> riscado; $\mathrm{MB}$ forades; $\mathrm{AB}$ fordes.

Dime algùnha còusa dòce

como habes doito, écatá,

que Si asi no no fazèdes,

24 me escatímo, évelo hàs.

$22 \mathrm{O}<\mathrm{c}>$ de catá semella sobrepoñerse a un $<\mathrm{t}>$ subxacente. $23 \mathrm{O}<\mathrm{S}>$ de $\mathrm{Si}$ semella corrixir as dúas primeiras letras dun asi subxacente; fazèdes corrixe un faguèdes subxacente por medio dun $<\mathrm{Z}>$ colocado na entreliña, sobre as letras < $<$ riscadas. $24 \mathrm{MB}$ hàis no canto de hàs; $\mathrm{AB}$ hais.

Ven sabedes, vaiche bòa!

como estas cousas se fàn, madia tendes, senon

28 eu eime de encabujar.

27 Antes de madia lese un è riscado; $\mathrm{MB}$ é madia; $\mathrm{AB} e$ madia.

Sospeito, polo que vejo non qués amiña amistà, fas ben, mais escom' así outra com' ela n’ achás,

32 Lese coma corrixido para com'; n' $t$, co <a> riscado, está na entreliña e por baixo, riscado tamén, lese non. 
Ramón Mariño Paz

Revista $\underset{\text { de } f \text { iloloxía }}{\operatorname{at}} \operatorname{Ga}$

Deisome evtaix à mece cabo layandome do men male, que abo filloy faxto teño; granizy aDaif que mo La"?

Dinichemen tántes as voficiooner of feito, é ánida maciv, que de dia, nim de nocte eu nunco podo dicusañ? Geño mottos calcelicios, a geentrexa ber Detraiv, reces, si hie " mal coctits, Dior che met axixea setoct. Vos menter en Diup do Céo, Coaxims podo achais, Soria cucitadina bá. nom teñs Pay, min eray!

Estouche fito un. Castabier,? èar vaproy dos ofly can

$\overline{68}$ 
$<1 \mathrm{c}>$

Deixame estàr à meu cabo

layandome do meu mal,

que abo fèllas farto teño;

36 grasias aDeus, que mo dà!

36 MB e AB gracias; Deus corrixe unha palabra subxacente que semella ser Dios.

Dòncheme tànto as sofràxes

ô Peito, è aínda màis,

que de dia, nin de nòite

40

eu nunca podo acougàr.

Teño moitos calafrios, á quentura ben detràs, receo, si hè ò mal catìbo,

$44 \quad$ Dios che m' arrede detàl.

$42 \mathrm{MB}$ ven detrais; $\mathrm{AB}$ ben detráis. $43 . \mathrm{MB}$ cativo. 44 Lese me corrixido para m'; $\mathrm{MB}$ me arrede.

Soi mentes en Deus do Céo, agarimo podo achàr, pois cuitadiña de min; já non teño Pay, nin Nay!

45 Deus corrixe unha palabra subxacente que semella ser Dios. 48 já está na entreliña e xà, riscado, lese debaixo.

Estouche feita un Cadabre, èas vagoas dos ôllos cán 
Ramón Mariño Paz

Revista $\underset{\text { de } f \text { iloloxía }}{\text { a }}$ Ga

ci comter me Len no Leyto: aij minix Vixigen doe Pas.' Jesta nom dou de cartar

vor ofeerzo dix allod (poij con ases relocen) por vi Henedis me dais.

Polo lia Duma ruca aisto

- Gaxamo veme bay,

C. Contafixar coideciche

que acabotar de mians.

ctingue a' pxea nom haguance

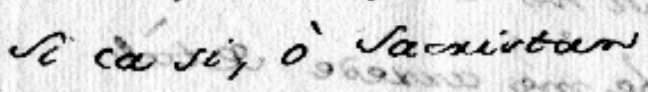

Devize a pestáma do finado

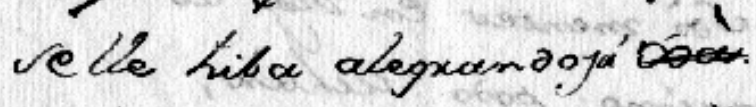

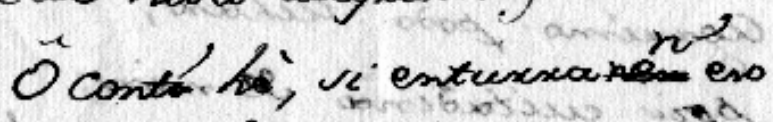

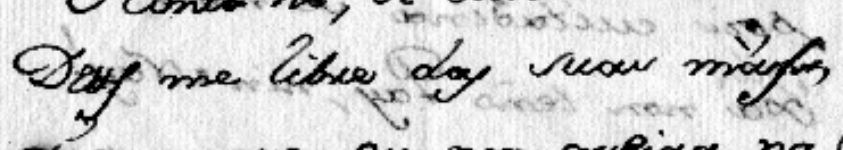

angue ew non gulix na Coba de chantaxme neere copas.

$\overline{70}$ 
$<1 \mathrm{~d}>\quad$ à cantos me ben no Leyto:

49 Podería ser Calabre, co $<\mathrm{d}>$ corrixido para $<\mathrm{l}>$. 51. MB leito. 52 É posible que $\mathrm{o}<\mathrm{g}>$ de Virgen corrixa un $<\mathrm{x}>$ subxacente.

Se d' esta non dòu de costas

vos ofrezo dir alá

(pois còas dores relouco)

56 por si remedio me dais.

53 No principio do verso lese Se co segmento stanno riscado. 55 AB Dores, coa seguinte explicación: "M. B. 'dores', que nos afrontamos a pór con maiúsculas, por coidar que é alusión á Virxe dos Dores, de Fruime, según se deduz do contesto 'reloucar'; trataráse dun xogo de verbas".

\section{Polo fio d' unha roca \\ ó estagamo seme bay, é cortafeira coideiche}

60 que acababa de finar.

Anque à prea non hégrande

si ca si, ò Sacristan

disque à pestana do figado

64 se lle hiba alegrando já.

64 Despois de já lese xà riscado; MB iba...xa.

Ô cont' hè, si enturra n' eso

Deus me libre das suas màs, q' anque eu non queira, na Coba

68 de chantarme heche capáz.

65 Lese conto corrixido para cont'; MB conto he; o $n$ ' de n'eso está na entreliña, e por debaixo lese $\mathrm{MB}$ enturran'eso. 66 Deus corrixe unha palabra subxacente que semella ser Dios; màs podería estar corrixindo un máns subxacente. 67 Antes de anque lese que corrixido para $q$ '. 
Ramón Mariño Paz

Revista de a filoloxía

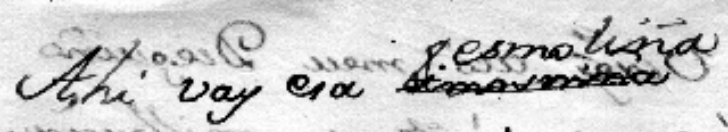

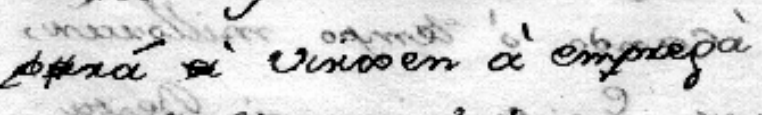
que che lla dou de 60 so menter:

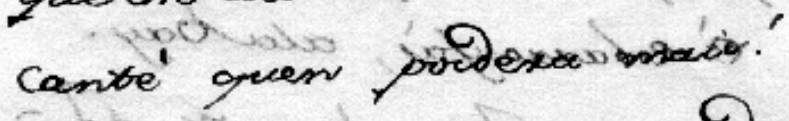

Es ne unho piobe zund mach pocodo de minhts ä̈'ín

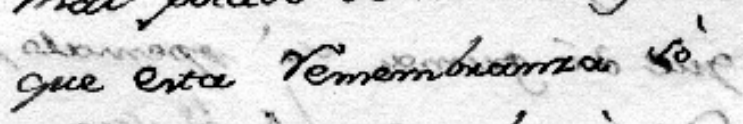
me tay decorie charvacia urona denoño ben vabe o'tamano secure mále,

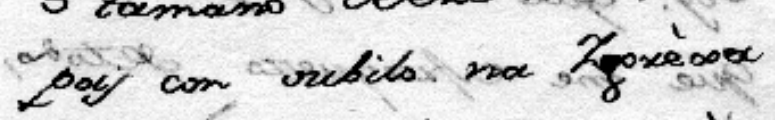
(vos menzy) á venteic doa's Tamen boy ere tabogue mee velliño, poir fempox que coda gxas wet goxenta, con eso as tremgy Lacixam.

$\overline{72}$ 
$<2 a>$

Ahí vay esa esmoliña prá Virxen à empregà que che lla dou de boa mentes;

72 cantè quen poidera mais!

69 esmoliña está sobreposto e por baixo, riscado, lese limosna. 70 Lese pará, co primeiro <a> riscado, e antes de Virxen lese à riscado.

Eu só unha probe viuda mal pocado de min! aÿ! que esta remembranza sò

76 me fay decote choràr.

73 Podería haber un $<\mathrm{n}>$ riscado despois de só; MB una.

Nosa Señora ben sabe ó tamaño deeste màl, pois con oubilo na Ygrèxa (soi mentes) ó sinteu xà.

80 MB sinten; AB [ela ben] o sintéu xa, coa seguinte explicación: "hai unha falla no ms., que interpretamos antre claudatos".

Tamen bay ese tabaque meu velliño, pois fungàs que cada grao de èl gorenta,

84 con eso as fremas sairàn.

81 tabaque corrixe unha palabra subxacente que non se recoñece. 


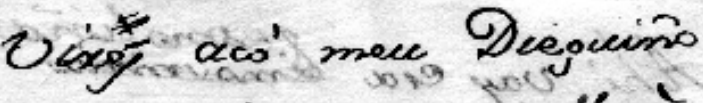

candas 'ó tempo millosecen,

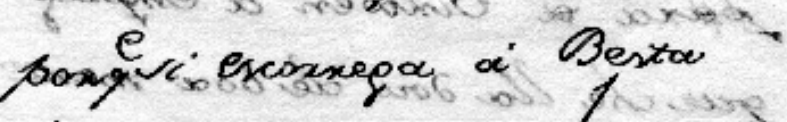

e'vebaxneyti, ala bay.

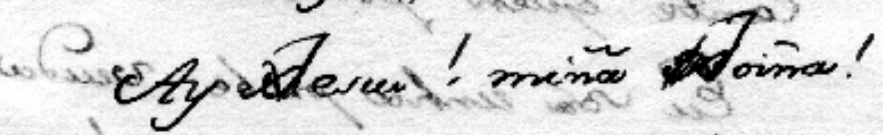

nonitatemas presto maciv,

gue dá guma vo' pomalo,

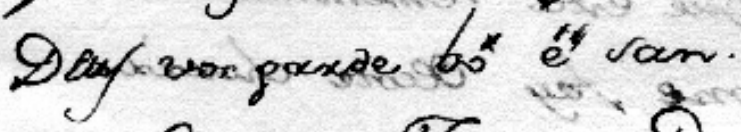

Aantiage Febreixo Joce

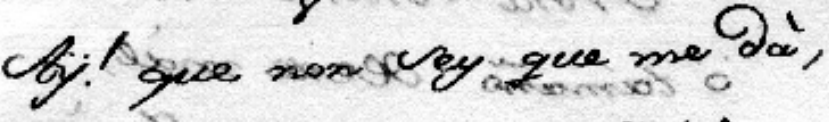

quie the enfragherps detod,

enom pro vafesain. को

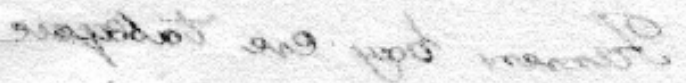

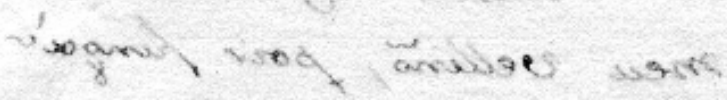

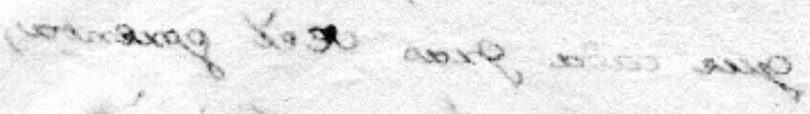

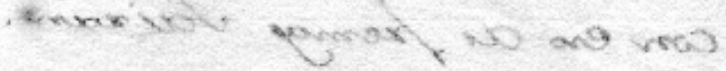


$<2 b>$

Virás acò meu Dieguiño cando ò tempo milloràr, porq ${ }^{e}$ si escorrega á Besta è esbarroufàs, alabay.

85 Lese Viràs corrixido para Virás. 88 AB esbarroufas.

\section{Ay Jesus! miña Joiña!} non falemos nesto mais, que dá grima sò pensalo,

92 Deus vos garde bó é san.

$89 \mathrm{O}<\mathrm{J}>$ de Jesus e o de Joiña corrixen cadanseu $<\mathrm{X}>$ subxacente; MB xoiña. 92 Deus corrixe unha palabra subxacente que semella ser Dios; os tiles de bó e de é corrixen tiles anteriores riscados.

\section{Santiago, Febreiro doce}

Aÿ! que non sey que me dà, que me esfraquezo detodo,

96 ènon podo vafexàr. 


\section{Estudo lingüístico ${ }^{4}$}

\subsection{Nivel gráfico}

Os que escribiron algo en galego durante o século XVIII foron persoas alfabetizadas en castelán que habitualmente escribían tamén neste idioma, é dicir, no idioma en que, ao lado dun xa declinante latín, se escribía e publicaba preferentemente por aquel tempo tanto no reino de Galicia coma en todo o reino de España. Aquel ocasional labor de escritura en galego debíase afrontar sen posible recurso a ningún autor ou institución adornados da autoridade necesaria para inspirar, se non unhas normas ortográficas propiamente ditas, si cando menos unhas mínimas orientacións na materia. As propostas que a este respecto ideara o Padre Sarmiento desde mediados da década de 1740 , ao igual ca a súa contemporánea práctica escrituraria en galego, quedaran sepultadas tras a súa morte nos seus inéditos manuscritos, con case nulas posibilidades de influír sobre as prácticas doutros individuos.

Pola súa parte, a ortografía castelá da época vivía un momento en que as distintas propostas elaboradas e publicadas pola Real Academia Española a partir de 1726 non conseguían máis ca unha deficiente socialización que causaba o reiterado lamento daquela institución que, auspiciada pola dinastía borbónica reinante en España desde 1700, botara a andar no 1713. Deste xeito, o paulatino abandono dos criterios máis estritamente etimoloxizantes que os académicos españois foron dispoñendo durante o XVIII e as primeiras décadas do XIX bateu sobre todo coa rémora dos usos gráficos secularmente transmitidos, que comezarían a ceder significativamente mercé á política de extensión do ensino primario e de difusión escolar da ortografía da RAE posta en marcha durante o reinado de Isabel II.

Nestas circunstancias, resulta natural que case todos os ocasionais escritores en galego do século XVIII, como tamén a maioría dos algo máis tardíos, transvasasen para esta lingua "de ocasión" os hábitos gráficos que desde rapaces asumiran para a lingua en que habitualmente escribían, coa única excepción dos contados aspectos en que as diverxencias dos sistemas fonolóxicos galego e castelán o impedían. Obviamente, esta reflexión de alcance xeral é aplicable ao romance a Diego Cernadas que aquí analizo, tanto se as súas características gráficas deben atribuírselle en excluiva á súa autora coma se obedeceron, cando menos parcialmente, a posibles intervencións do copista.

4 Neste estudo pretendo analizar a lingua do romance de María Francisca de Isla inseríndoa no marco das tendencias observables na escritura en galego dos Séculos Escuros e do Prerrexurdimento. Para non cansar o lector con repeticións constantes, declararei nesta nota que a maioría das afirmacións relativas aos usos propios do galego oral e escrito daquela época están tomadas de Mariño Paz (1995), Mariño Paz (2000) e Mariño Paz (2003). 
Unha das maiores dificultades que levantaba a escritura en galego naquela época era o da grafización do fonema fricativo prepalatal xordo. Aínda que os subsistemas de consoantes fricativas non evoluíran converxentemente no galego e no castelán posmedievais, o certo é que si se podían establecer entre eles algunhas equivalencias que posibilitasen acomodar para o galego as normas que ao respecto preconizou a RAE a partir de 1726. No "Discurso Prohemial de la Orthographía de la Lengua Castellana" que incluía na primeira entrega do seu Dicionario de Autoridades, a Academia consideraba $<\mathrm{j}>,<\mathrm{x}>\mathrm{e}<\mathrm{g}>$ como letras "unísonas", pois a primeira soaba /x/ ante calquera vogal, á segunda pasáballe o mesmo aínda que en bastantes casos o que representaba realmente era o grupo /ks/ (examen, exonerar, etc.) e a terceira soaba /x/ ante vogal palatal. O uso das tres grafías regulábase por medio dun criterio esencialmente etimolóxico: $<\mathrm{g}>$ cando os étimos das palabras contivesen esta letra (elegir, regir, etc.); $<\mathrm{x}>$ co valor de /x/ cando os étimos presentasen $<\mathrm{x}>$ (relaxacion, exemplo, vexiga, enxundia, etc.) e tamén "quando las voces tienen en su orígen s: como Caxa, Dexar, Xabón, Xugo, Xeme, que salen de Capsa, Deserere, Sapo, Succus, Semipes: y la razón es, porque la $s$ tiene el sonído muy parecido al de la $x$ : y como los Españóles tomamos de los Arabes la pronunciación guturál, y estos pronúncian las ss como $x$, es natural la conversión de la $s$ en $x$, y no en $j$ " (RAE 1726-1739: I, LXXIV); <j> nos restantes casos (jaspe, paja, etc.). Poderiamos dicir que no romance de María Francisca de Isla poderían ser o resultado dunha adaptación a estas disposicións os casos de Virgen (52), Deixame (33), vejo (29), já (48, 64), Jesus (89), Joiña (89) e se cadra tamén Ygrèxa (79) -por ter $<$ s $>$ no seu étimo-, pero non con certeza sofràxes $(37,<$ lat. SUFFRAGINES), Virxen (70), xà (80) e vafexàr (96, sufixo latino -ǏI $\breve{I} \bar{A} R E$.

Ora ben, as normas preconizadas pola RAE estaban claras na teoría, pero tiñan que ocasionar moitos problemas de aplicación práctica, tanto no propio uso castelán coma na súa adaptación ao galego. Na miña opinión, as voces privativas do galego revelaríanse como particularmente problemáticas, pois carecerían de referencia orientadora na lingua oficial e nalgúns casos tamén no portugués. Así, os étimos do substantivo sofràxes e do sufixo -exar de vafexàr poderían estar ao alcance dunha persoa moi versada en latín antigo e medieval e en fonética histórica das linguas románicas (coma o Padre Sarmiento), pero non ao da xeneralidade dos escritores. Canto a encabujar (28) e o substantivo cabuja, sería dificultoso establecer un étimo certo para o seu sufixo - uja, como tamén para puja (11), que na exclamación ai dá puja! lle suxeriu hipóteses etimolóxicas distintas a Sarmiento ${ }^{5}$,

\footnotetext{
Estando en Pontevedra en 1754 o bieito anotou o seguinte: "Pucha! Interjección de alegría, v. g.: Pucha!, Ay da pucha!, Ay da puchiña! Es ponderar el gusto de una fruta, de un vino, de un manjar, etc. Hace casi como el canté afirmativo, no el canté optativo. Todo consiste en el retintín. En Santiago puxa. ¿Si de putia?” (Sarmiento 1973: 399). E ao ano seguinte, tamén en Pontevedra, escribiu isto: “Ay da pucha y ay da puxa y ay da puxiña o puchiña. Véase atrás. Estoy persuadido a que esa expresión gallega es trastornación de esta otra expresión castellana: ah hi de puta!, ay de puta, ay da puta, pucha,
} 
Saco Arce ${ }^{6}$ e outros. Tampouco estaba exento de dificultades o adxectivo quixòsa (7), xa que o seu étimo distaba de ser trivial ${ }^{7}$ e ademais, aínda que a RAE optase pola forma queja no seu dicionario, existía un uso secular de quexa que sen dúbida mantivo a súa influencia durante moito tempo e que no galego escrito da época podía favorecer o emprego de queixa no canto de queija.

No interior do propio texto dáse unha variación entre Virgen (52) e Virxen (70) e entre já $(48,64)$ e xà $(80)$ que creo se debe conectar co feito de no manuscrito estaren patentes as dúbidas do amanuense ante certos casos implicados neste problema gráfico, pois ata en cinco ou seis ocasións atopamos formas inicialmente escritas con $<\mathrm{x}>$ que foron riscadas para despois substituílas por outras con $<\mathrm{j}>$ ou $<\mathrm{g}>$ : isto é o que ocorre entre puxa e puja (11), entre xà e já $(48,64)$, entre Xesus e Jesus (89), entre Xoiña e Joiña (89) e probablemente tamén entre Virxen e Virgen (52). A meu ver, o que isto pon de manifesto é que quen escribiu estes versos se debatía entre as seguintes dúas tendencias: adoptar un criterio fonoloxicista e simplificador axeitado ás particularidades do galego neste punto do seu sistema fonolóxico (escribindo sempre $<\mathrm{x}>$ ), ou manter o tradicional emprego "promiscuo" de $<\mathrm{g}>$, $<\mathrm{x}>\mathrm{e}<\mathrm{j}\rangle$, talvez buscando algunha orientación nas propostas da RAE e nos usos secularmente establecidos no castelán. Carezo de indicios que me poidan inclinar a supoñer que na súa praxe puideron pesar tamén referencias tales coma o do galego medieval ou o de idiomas románicos próximos coma o portugués ou o francés.

Promiscuo era precisamente o adxectivo que a RAE (1726-1739: I, LXXIILXXIV) utilizaba no proemio ortográfico de 1726 para cualificar o uso que desde había moito se viña facendo en castelán dos signos gráficos $<c ̧>$ e $<\mathrm{Z}>$. Para poñer orde e maior clareza neste asunto dispoñía que se abandonase o emprego de $<c ̧>$, mais cautamente mantiña o emprego de $<\mathrm{z}>$ e $<\mathrm{c}>$ co mesmo valor fonolóxico: o primeiro ante vogal non palatal (<za, zo, zu>) e en posición de coda silábica (paz) e o segundo ante vogal palatal $(<\mathrm{ce}, \mathrm{ci}>)$. Contravén estas normas a voz castelá Romanze, que aparece no encabezamento do manuscrito que aquí estudo, pero acomódase a elas unha boa presada de palabras galegas: concencia (5), cubizár (12), rapàz (18), dòce (21), receo (43), Céo (45), Paz (52), ofrezo (54), capáz (68), remembranza (75), doce (93) e esfraquezo (95). Non obstante, tamén se atopan nos versos do romance tres formas con solucións gráficas distintas das propugnadas pola academia española para o castelán: esquenzerei (19), fazèdes (23) e, na miña

puchiña, puxa, etc. Creo que Sancho Panza la usa en el sentido en el cual la usamos los gallegos" (Sarmiento 1973: 430). Tendo en conta a existencia do eufemismo pucha por puta en castelán, Corominas e Pascual aceptan a proposta de Sarmiento. (cf. DCECH, s. v. puta).

6 Esta era a súa conxectura: "Eidapuxa (ehi-da-puxa, ahí de la subasta) espresa admiracion ó aprobacion irónica de alguna cosa extravagante" (Saco Arce 1868: 140).

7 Véxase no DCECH un resumo do debate que sobre esta cuestión mantiveron os especialistas. 
opinión, tamén a seseante grasias (36), para a que MB e AB ofrecen a lectura gracias, que non representa explicitamente o seseo.

Se do $<$ ç $>$ xa non hai rastro no poema de Isla y Losada, tampouco o hai do ese duplo $(<\mathrm{ss}>)$, que fora abolido pola RAE para o castelán na reforma ortográfica de 1763.

O tratamento simplificador para facilitar o uso das "letras que se equivocan en la pronunciación" (RAE 1726-1739: I, LXXI) tamén se impuxo en 1726 para os pares compostos por $<\mathrm{u}>$ e $<\mathrm{v}>$ e por $<\mathrm{i}>$ e $<\mathrm{y}>$, respecto dos cales se dispoñía que $<\mathrm{u}>$ e $<\mathrm{i}>$ se utilizasen só con valor vocálico (usted, silbar) e $<\mathrm{v}>\mathrm{e}<\mathrm{y}>$ só con valor consonántico (voz, yantar, ayuno), con poucas excepcións. Ora ben, asentado isto, cumpría resolver o vello problema de como empregar correctamente $\langle$ b $>$ e $<$ v $>$ para representar o mesmo valor consonántico, xa que "el uso de la $B$, y de la $V$ causa mucha confusión, nacida de que los Españóles, como no hacémos distinción en la pronunciación de estas dos letras, igualmente nos hemos valido yá de la $B$, yá de la $V$, sin el menor repáro" (RAE 1726-1739: I, LXXII). Coma noutros casos, a solución que se propoñía era de inspiración etimolóxica: $<\mathrm{b}>$ empregaríase cando nos étimos houbese $<\mathrm{b}>$ ou $<\mathrm{p}>$ (barba, amaba, cabeza), formando grupo consonántico homosilábico con líquida ou vibrante (amable, bronce) e cando non se puidese establecer con certeza a orixe da palabra afectada "porque es mas connaturál à nuestra manéra de hablar la pronunciación de la $B$, que de la $V$ "; $<\mathrm{v}>$ usaríase coas voces que viñesen de étimos que tamén a contivesen (vanidad). Neste aspecto das consoantes labiais os desenvolvementos históricos dos sistemas consonánticos galego e castelán foran paralelos e deberon de consolidarse xa na Idade Media, polo que os escritores en galego do século XVIII podían acomodarse doadamente ao que en 1726 propuxera a RAE para o castelán. Tal parece ser o caso dun numeroso grupo de palabras do romance ao cura de Fruíme: ben $(3,17,31,77)$, vòlva (9), cubizár ${ }^{8}$ (12), vesita (14), lembro (16), habes (22)9 , sabedes (25), Cadabre (49), acababa (60), hiba (64), etc. De vafexàr (96) debemos dicir que, aínda que obxectivamente contraviña a doutrina da Academia, respectaba en troques o modelo propagado de feito desde o Dicionario de Autoridades, onde aparecían as entradas vahear e vaho, grafadas con $\langle\mathrm{v}\rangle$ porque se relacionaron co latín VAPŌRE. No entanto, no romance de dona María Francisca aínda se lle pagaba un alto tributo ao tradicional uso "promiscuo" de $<\mathrm{b}>\mathrm{e}<\mathrm{v}>$ combatido pola RAE, que podemos ilustrar con varios exemplos: vote ${ }^{10}(2)$, ven 'ben' $(25)$ ao lado de ben $(3,17,31,77)$,

8 O Dicionario de Autoridades aínda recoñecía cobdiciar ao lado de codiciar.

9 Con todo, a RAE aínda vacilou un tempo entre a innovación haber e o vello haver, por máis que no Dicionario de Autoridades dixese que "sale del latino Habére, por cuya razon se debe escribir Haber, y no Aver, como hacen muchos" (RAE 1726-1739: II, s.v. haber).

${ }^{10}$ O Dicionario de Autoridades recollía o verbo botar, con $\langle\mathrm{b}\rangle$, do que dicía que "tiene ya poco uso, excepto en Galicia" (RAE 1726-1739: I, s. v. botar). 
ben 'vén' (42), ben 'ven' (51), bay (58, 81, 88) ao lado de vay (69) e Coba (67). Outro tanto cómpre afirmar a propósito de vèrbos (10), onde o clítico se escribía con $\langle\mathrm{b}\rangle$ ao contrario do que se facía en évòs (12) -que inicialmente era un ébòs que despois foi corrixido-, vòs (16), vós (17) e vos $(19,54,92)$, reproducíndo así unha antiquísima práctica que a RAE (1726-1739: I, LXXII) condenara expresamente:

Esto se debe observar en qualesquiera dicciones enteramente, y no con la bárbara distinción que ha introducido la ignoráncia de que no ha de haver dos $B B$, ù dos $V V$ en una palabra, porque si en su raíz las tienen: como en Barba, Beber, Barbaridád, Volver, Vivir, qué motívo se puede dár para escribír Barva, Bever, Barvaridád, Bolver, Bivir, ò al contrario Varba, Veber, Varbaridád, Volber, Vibir.

Pola súa parte, as voces vagoas (50), oubilo (79) e catibo (43) deberon de suscitar non poucas dúbidas, quer pola difícil determinación do seu étimo (no caso de vago$a s$ ), quer pola carencia dun referente en castelán (no caso de oubilo e tamén de vagoas), quer pola particularidade semántica da palabra galega no caso do adxectivo catibo, que en castelán se debía escribir con $<\mathrm{v}>$ (cativo ou captivo).

Da norma de lle reservar a $<\mathrm{y}>$ o valor consonántico e a $<\mathrm{i}>$ o vocálico só escaparon en 1726 os vocábulos de orixe grega en que $<y>$ se viña utilizando "para no desfigurarlos de su orígen" (ázymo, martyrio, sylaba, etc.), a conxunxión copulativa $y$ polo seu "uso común [...] tan asentado" e os nomes que remataban en ditongo decrecente con [j], para os cales se consideraba necesario manter a conformidade entre singular e plural, tendo en conta ademais que no plural $\mathrm{o}<\mathrm{y}>$ si representaba consoante (rey - reyes, comboy - comboyes) (RAE 1726-1739: I, LXXILXXII, LXXXIV). Estas normas fóronse reaxustando durante o XVIII e o XIX, e para quen se aproxime a este romance galego de entre 1774 e 1777 resulta conveniente saber que na sexta edición da súa Ortografia a RAE (1779: 51-56) dispoñía que se abandonase definitivamente o uso de $<y>$ nas voces de orixe grega que o levaban nos étimos, que se empregase -con algunhas excepcións- nos ditongos decrecentes non só en posición final de palabra senón tamén na interior (ayre, Reyna) e que como maiúscula se utilizase $<Y>$ no manuscrito (Yglesia, Ysla) mais non no impreso. Non se axusta por completo a estas disposicións a copia do poema galego de Isla y Losada, mais tampouco discorda respecto do que por volta de 1775 se adoitaba facer no castelán. Como núcleo silábico escríbese <i $>$ (aloumiñar, 8; min, 6; cubizár, 12; etc.), coas excepcións de Ysla e y (no castelán do encabezamento) e de Ygrèxa (79), xa previstas pola RAE para os manuscritos. Na marxe posnuclear interior de palabra predomina amplamente $<\mathrm{i}>$ (despois, 3; enteimàr, 20; doito, 22; etc.), coa única excepción de Leyto (51). Na marxe posnuclear final de palabra prepondera o uso concordante co preconizado pola RAE, con só tres 
excepcións que en ningún caso aparecen máis alá da quinta cuarteta: Sei (1), ai (11), esquenzerei (19), pero Pay (48), Nay (48), ä̈ (52, 74), vay (69), fay (76), bay (81, 88), Ä̈ (94), sey (94). Na marxe prenuclear posconsonántica só se usa <i>: concencia (5), grasias (36), Dios (44), remedio (56), Dieguiño (85). Finalmente, en posición interior intervocálica o emprego de $<\mathrm{y}>$ (layandome, 34), común tamén nos textos do Prerrexurdimento, está inducido polo valor consonántico que a RAE lle atribuía a $<\mathrm{y}>$ en palabras castelás como mayo e playa.

Canto ao emprego do grafema $<\mathrm{h}>$, a doutrina que a RAE foi propalando a partir de 1726 consistía nunha prudente acomodación ao criterio etimolóxico, debidamente compensada co tributo aos usos establecidos en voces coma oy 'hoxe', armonía, as que tiñan ditongo [we] en posición inicial (hueco, huevo, hueso...) ou aquelas en que $<\mathrm{h}>$ podía funcionar como marca de hiato (albahaca). No romance ao cura de Fruíme chama a atención e preponderancia do uso de $<\mathrm{h}>$ coas formas do verbo haber (has, 8; habes, 22; hàs, 24; exceptúase eime, 28), é dicir, o alto grao de acatamento dunha norma de inspiración etimolóxica na que a RAE puxera moito empeño, pois era moi forte a tendencia de moitos a seguir escribindo haber sen $<\mathrm{h}>$, como se viñera facendo desde antano. A preferencia polas formas con $<\mathrm{h}>$ para a P3 do presente de indicativo de $\operatorname{ser}$ (hè, 43, 65; hé, 61; heche, 68; exceptúase évòs, 12), patente tamén nos textos das primeiras décadas do século XIX, probablemente respondía ao desexo de diferenciala da conxunción copulativa $e$. Antietimolóxico era tamén o uso de $<\mathrm{h}>$ en hiba (64) e igualmente en Ahí (69), mais con este adverbio esta opción amparábase na práctica preconizada pola RAE, que semellaba fundarse no valor de marca de hiato que lle asignaba a <h>: "AHÍ. Adv. de lugar. [...] Algunos le escriben sin la $h$; pero parece mas natural la tenga, respecto del modo de su pronunciacion" (RAE 1726-1739: I, s. v. ahî).

No tocante á representación da consoante nasal velar en posición intervocálica interior de palabra, este texto é un dos poucos elos da pequena cadea que marca o afianzamento do uso do dígrafo $<\mathrm{nh}>$ durante o século XVIII (cf. Mariño Paz 1999: 294-295): algùnha (21), unha (57, 73). En todo caso, dada a carencia dunha auténtica tradición de escritura en galego durante o setecentos, debemos advertir de que consolidación do emprego de $<$ nh $>$ propiamente dita non a haberá ata o século XIX.

Sorprende a utilización da diérese sobre a semiconsoante da interxección a $\ddot{y}$ (52, $74,94)$. Poida que se trate dun recurso para indicar que as dúas vogais se debían pronunciar sen pausa silábica intermedia. Con todo, tamén se le Ay (89).

En conxunto, creo que este poema da Perla Galega amosa unha ben perceptible tendencia ao acatamento das disposicións ortográficas defendidas pola RAE, mais coas habituais excepcións ou vacilacións dos textos galegos de todas as épocas anteriores ao proceso de estandarización iniciado ao final do século XX. Máis 
aínda, no XVIII e antes do XVIII o polimorfismo gráfico era unha característica xeneralizada non só dos textos galegos, senón tamén de moitos dos producidos en castelán, como ben deixa ver o seguinte lamento da Academia Española publicado en 1726 :

Si en estas [nas obras modernas] se hallasse la igualdád y conformidád debida, con facilidád se huviera fijado una competente Orthographía; pero lo sensible es que los Autóres no tan solamente están entre sí discordes, sino que en sus mismas obras se hallan escritos con variedád unos mismos vocablos. Esta irregularidád y defecto es tan indecoroso y ofensivo de la nobleza y lustre de la Léngua, que siendo en sí purissima, elegante y clara, la hace obscúra, intrincada y dificultosa: y al passo que dá motívo para que se dude en muchas palabras el modo con que se deben escribir, ocasiona en los extraños el embarazo de que dificulten ò no alcancen lo que se quiere dár à entender, por hallarlas diversamente escritas (RAE 1726-1739: I, LXVII).

\subsection{Niveis fónico, morfosintáctico e lexical}

Canto a estoutros outros niveis da análise lingüística, considero que esta composición de María Francisca de Isla se caracteriza polo seu marcado ton coloquial, polo seu alto grao de enxebreza (con baixo impacto do castelanismo) e pola súa coloración dialectal compostelá. En conxunto, pódese ler como o testemuño da elevada competencia en lingua galega que no último terzo do século XVIII mantiña unha distinguida dama da fidalguía urbana santiaguesa.

Respecto da primeira das tres características do texto que anteriormente enunciei, comezarei afirmando que o lector deste romance se sente desde o primeiro verso impelido a consideralo coma se de parte dunha distendida conversación rimada se tratase. A interxección apelativa con que ese verso e o poema todo se inician marca o ton de diálogo informal que non se abandonará ata o remate: "Ôu mèu Crego? Sei q' qués, / que eu vote alengua â paseàr?" (1-2). Sentimentos e reaccións de diverso tipo experimentados pola emisora denota ;ay!: "ä̈ miña Virgen da Paz!"

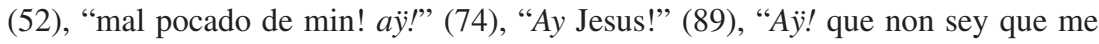
dà" (94). Conformidade co dito inmediatamente antes é o que expresa a interxección madía, que aquí se emprega non na súa construción fixada co verbo levar, senón na que posúe con ter:

Ven sabedes, vaiche bòa!

como estas cousas se fàn,

madia tendes, senon

eu eime de encabujar (25-28). 
Que a forma que esta copia do romance nos transmite é a trisílaba madía confírmase polo feito de no manuscrito estar riscada a conxunxión copulativa é que se escribiu no principio do verso 27 e que na súa edición deixaron estar tanto Martínez Barbeito coma Xosé María Álvarez Blázquez. A omisión desa conxunxión implica que a interxección se debe ler aquí madía, e non madia, para que o verso teña a medida oportuna ${ }^{11}$.

Funciona tamén como interxección mal pocado, que no verso mal pocado de min! $a \ddot{y}$ ! (74) se asocia cun pronome oblicuo rexido pola preposición de para expresar conmiseración da emisora respecto de si mesma (sen concordancia en feminino e singular, o que evidencia que non estamos ante un adxectivo). No galego moderno esta posibilidade construtiva preséntana tamén outras interxeccións, e nomeadamente ai (cf. Álvarez / Xove 2002: 671). ¡Malpocado! procede de imal pecado! ${ }^{12}$, unha expresión para a que existen documentacións medievais e posmedievais en galego, portugués e castelán (cf. DCECH; Lorenzo 1975-1977: II, 796) e que no noso idioma chegou a gramaticalizarse non só como interxección, senón tamén como adxectivo dotado das flexións de xénero e número que ten o significado de 'coitado' ou 'desventurado', coma na seguinte pasaxe dunha obra de Avelino Rodríguez Elías (1930: 107): “Triste sorte a sorte miña: tolleito, probe e sin dona, astra o fillo me levaron ó servizo, e desta choza metido antr' as catro pedras, agardo que chegue a hora derradeira desta vida malpocada".

Dos diversos valores que en 1745 lle recoñeceu Sarmiento (1973: 269-270), é o optativo, o de expresar un "deseo de cosas poco asequibles" (Saco Arce 1868: 139), o de "ojalá" (Sobreira 1979: 438), o que canté presenta neste romance: "cantè quen poidera mais!" (72). Antecedente aínda non gramaticalizado da interxección dodemo é precisamente a exclamación ;dou ao demo!, coa que se interpela o demo coa intención de negar rotundamente a posibilidade de seren executadas as accións que se enuncian inmediatamente despois: "s' àvesita non pagàs / dou ò Demo pè ala poño / nin me lembro de vòs màis" (14-16). Outras exclamacións intensifican aínda máis o sabor coloquial do romance:

- ai dá puja! (11), para a que remito de novo ás glosas de Sarmiento e Saco Arce que máis arriba transcribín, expresa admiración ante a conxectura que a poeta lanzara nos versos inmediatamente anteriores: que

${ }^{11}$ Con toda a certeza, no século XIX xa recolleron a variante madía, entre outros, o autor dun vocabulario anónimo galego-castelán de entre 1840 e 1850 (Pensado 1995: 63), Saco Arce (1868: 140) e Valladares (1970: 115). Dubidoso canto á acentuación é en troques o testemuño de Sobreira (1979: 369).

12 Xa Sarmiento (1973: 270) lle apuntou esta orixe en 1745: "Pocado, por pecado. Sólo se usa en la expresión mal pocado, y sirve para mucho, y en especial para condolerse". Así e todo, no mesmo ano o bieito barallou tamén a posibilidade de derivar a expresión do adxectivo apocado (cf. Sarmiento 1973: 328). 
poida que o abade de Fruíme lle pedise que lle escribise unhas letras para así evitar que fose ela mesma en persoa a velo de balandrán na súa freguesía da montaña lousamesa; como expresión de admiración e de alegría, xa o propio Cernadas a empregara nas coplas que compuxera en 1759 co gallo da coroación de Carlos III como rei de España, inseridas nun escrito do que se fixo publicación autónoma en vida do seu autor (cf. García Cortés 2002: 236-239): "Diz que xá ten oito fillos, / seis Varons, duas Infantas: / endeben, casi me folgo: / aidapuxa; casi hé farta" (Cernadas y Castro 1778-1781: V, 183);

- vaiche bòa! (25) encarece a corrección da afirmación en que se incrusta, indicando quizais que aquilo que se di é algo que acontece desde hai moito tempo: "Ven sabedes, vaiche bòa! / como estas cousas se fàn" (25$26)^{13}$

- alabay '¡alá vai!' (88) expresa que o atrevemento de Cernadas se decidise viaxar a Santiago durante a invernía tería un desenlace funesto se a súa cabalgadura escorregase polo camiño e tirase con el no chan: "Virás acò meu Dieguiño / cando ò tempo milloràr, / porq ${ }^{e}$ si escorrega á Besta / è esbarroufàs, alabay" (85-88).

- miña Joiña! (89), finalmente, denota "compasión y cariño" (Saco Arce 1868: 140).

Este ton coloquial crea condicións óptimas para que afloren os oito casos en que nestas vinte e catro cuartetas se usa o dativo de solidariedade, un recurso pragmático que a meu parecer xa se rexistra no galego medieval e que posteriormente aparecerá con notable abundancia nas fontes do galego medio e dos inicios do século XIX, impregnadas a miúdo dese mesmo aire de coloquialidade e de proximidade á lingua oral que impulsaría os seus autores cara ao seu emprego. As interpelacións de María Francisca de Isla ao cura de Fruíme válense constantemente de dativos de solidariedade, que se presentan ora na forma de trato cortés (vos), ora na moito máis frecuente forma de familiaridade (che):

- ai dá puja! q’ a terriña / évòs para cubizár (11-12)

- Dòncheme tànto as sofràxes (37)

- Dios che m' arrede detàl (44)

13 Pouco máis tardío ca o de Francisca de Isla é o testemuño insatisfactoriamente glosado que cara ao final do século XVIII recadou o Padre Sobreira (1979: 110): "AGORA. Interj. negativa y expresiva de sentimiento tenido por lo mismo que se niega, como: Ceache ja? Agora, nin en duas horas. Agora, vayche boa". 
- Estouche feita un Cadabre (49)

- é cortafeira coideiche / que acababa de finar (59-60)

- q' anque eu non queira, na Coba / de chantarme heche capáz (67-68)

- Ahí vay esa esmoliña / prá Virxen à empregà / que che lla dou de boa mentes (69-71).

Así mesmo, o dativo de solidariedade aparece contido na coñecida expresión exclamativa jvaiche boa!, que coa súa forma de familiaridade che se xustapón a unha forma verbal de P5 que implica tratamento deferente: "Ven sabedes, vaiche bòa! / como estas cousas se fàn" (25-26).

Se xa estes trazos de coloquialidade evidencian o alto grao de enxebreza e o reducido alcance da interferencia castelanizante que se perciben na lingua utilizada neste romance ao cura de Fruíme, creo que acontece o mesmo con outros fenómenos de índole fonética, morfolóxica, sintáctica, lexical ou semántica. Non teño datos que me inclinen a pensar que María Francisca de Isla puido considerar como modelos para a súa escritura en galego a lingua das obras e documentos medievais (que talvez descoñecía) ou a dalgún dos contados e moi ignorados autores posteriores; atrévome, iso si, a conxecturar que algunha inspiración puido atopar precisamente nos escritos do seu amigo Diego Cernadas, e se cadra tamén nos de José Cornide, a quen igualmente coñeceu e tratou. Creo, en fin, que o seu referente fundamental tivo que ser a fala popular da contorna compostelá, da que tamén era natural Cernadas e na que ela se criou e morou durante a maior parte da súa vida. Desa fala popular deben de proceder, nos planos fónico e morfonolóxico, alteracións vocálicas coma as de cubizár (12), vesita (14), estagamo (58), mal pocado (74) e milloràr (86), próteses coma a do alembro corrixido para lembro no verso 16, metáteses coma as de Cadabre (49), estagamo (58) e probe (73), destrucións de ditongos crecentes coma a de concencia (5), a redución a -á da terminación -ade que vemos en amistà (30) ou a coalescencia [ao] $>$ [॰] que se produce entre a vogal átona final de cata e o pronome enclítico $o$ en Catao (2), forma que debe lerse como bisílaba para que o verso "Catao ben, e despois non" teña a medida correcta.

Da mesma popular fonte provén a alternancia entre o trato de vós e o de ti para se dirixir a un amigo, que nos textos dialogados de principios do século XIX está sobradamente documentada. No seu romance dona María Francisca trata o cura de Fruíme de $t i$ nas estrofas $1,2,9,10,11,13,15$ e 17, de vós na 3, na 5, na 7 (coa excepción da expresión estereotipada jvaiche boa!), na 14, na 21 e na 23 e de ambas as maneiras na 4 , na 6 , na 8 , na 18 e na 22 . Os testemuños da época que conservamos amosan a evidencia de que naquel tempo había unha gran labilidade entre estes dous tipos de tratamento nesta clase de relacións amicais, de modo que en 
poesía as necesidades de medida e rima na construción dos versos podían inclinar o autor cara ao uso dunhas ou doutras formas sen que isto implicase realmente unha alteración da coherencia. Así, creo que foi a necesidade de usar formas verbais agudas rematadas en -ás ou en -á o factor que determinou a escolla de pagàs (14) e non pagas, de catá (22) e non cata, de achás (32) e non achas, de empregà (70) e non emprega, de fungàs (82) e non fungas; e paréceme que a autora optou por Dime (21) e non Dicídeme, Deixame (33) e non Deixádeme, Virás (85) no canto de Viredes e Dios che m'arrede detàl (44) en lugar de Dios me vos arrede detàl porque tiña que crear versos octosílabos.

Aínda que a súa manifestación no poema estea influenciada por factores métricos e rimáticos, non cabe dúbida de que a variación entre -des (fazèdes, 23; sabedes, 25) ${ }^{14}$, -s (pagàs, 14; habes, 22; achás, 32; fungàs; 82; esbarroufàs, 88) e -is (dais, 56) para a expresión do sufixo número-persoal da P5 dos presentes de indicativo e o emprego da desinencia 'cero' para a mesma persoa do imperativo (catá, 22; empregà, 70) está en sintonía co que hoxe presumimos sobre o uso compostelán daquela época, talvez coa excepción de dai $^{15}$. Útiles para o cumprimento da súa tarefa versificadora lle resultaron tamén as formas dòn 'doen' (37) e cán 'caen' (50), con elisión da segunda vogal do hiato (ou ben da semiconsoante palatal na fase doin, cain), que, considerando a distribución dialectal que para tran amosaba o ALGa 1 (mapa 384) ao final do século XX, ben podían ser usadas de contino en Compostela ou na súa redonda por volta de 1775. Quitando o relativo aos condicionantes métricos e rimáticos, cabe a mesma afirmación a propósito do sufixo número-persoal da $\mathrm{P} 2$ dos pretéritos de indicativo, para o que rexistramos -che e -ches (pensache, 6; trataches, 13), e tamén respecto da vogal temática da P3 dos pretéritos de indicativo da terceira conxugación: sinteu (80).

No terreo da morfoloxía dos verbos irregulares chamarei a atención sobre os seguintes aspectos:

- O uso do presente de subxuntivo de dea (20) e non de dé. Esta última é a solución maioritaria non só no galego medieval, senón tamén nas escasas fontes dos séculos XVI, XVII e XVIII e aínda nas de principios do XIX.

- A utilización exclusiva de formas con lexema $f a$ - (e non $f a c$-) para a P2, a P3 e a P6 do presente de indicativo do verbo facer, en liña co predo-

${ }^{14}$ En fordes (18) e tendes (27) non había opción para as desinencias -s ou -is, por non estar o /d/ de -des en contexto intervocálico.

15 Con todo, débese advertir que nas obras do cura de Fruíme se len relumbrais e sabereis (Cernadas y Castro 1778-1781: III, 305; VII, 389). Se as variantes con desinencia -is non estaban naquel tempo en uso polas terras de Compostela, María Francisca de Isla puido talvez aprendelas do seu amigo Cernadas, quen, por outra parte, tamén usou nos seus versos en galego as tres variantes -des, $-s$ e $-i s$. 
minio que delas se dá nos textos do setecentos e das primeiras décadas do oitocentos: fás (4), fas (31), fay (76), fàn (26). Digno de atención me parece que no verso 23 apareza a ourensá faguèdes como forma inicialmente escrita pero seguidamente desestimada a prol de fazèdes; ora ben, non hai forma de discernir se faguedes estaría xa no orixinal do que copiou Cornide ou se se debería en troques a unha iniciativa ou impulso do propio copista. En calquera dos dous casos, o coruñés preferiu finalmente a solución probablemente máis estendida.

- O emprego do lexema $i b$ - para o copretérito de $i r$, en consonancia co que é normal nas fontes dos Séculos Escuros e despois nas do século XIX: hiba (64).

- O uso do lexema poid-para o lexema do tema de pretérito de poder (poidera, 72), que tampouco estraña porque tamén se encontra en textos de ambientación compostelá producidos en 1812 e 1836.

- A decantación a prol da solución qués $(1,30)$ como P2 do presente de indicativo de querer, debida a que o seu carácter monosilábico lles aseguraba a medida correcta aos octosílabos en que se atopa.

- A utilización de só (73) como P1 do presente de indicativo de ser, con previa riscadura dun anterior són que se adiviña no manuscrito, o que coido que vén a corroborar a miña impresión de que na lingua oral dos séculos XVIII e XIX a variante (eu) so gozou de ampla circulación (cf. Mariño Paz 2003: 243).

A coloración dialectal compostelá, da que xa fun dando algunhas probas, percíbese tamén por outros indicios:

- lengua (2) como resultado da voz latina L L̆NGUA, aínda que tampouco nos causaría estrañeza a ocorrencia de lingua, unha variante que tamén se usa hoxe, como probablemente por volta de 1775, por Santiago e a súa contorna (cf. ALGa 3: mapa 77);

- a solución oi en palabras con étimos que contiñan os grupos -ŬCT-, -ŎCT- e -ǓLT- (doito, 22; nòte, 39; moitos, 41), coa aparente excepción, presente tamén noutras fontes compostelás un pouco máis tardías, do adxectivo cuitadiña (47), derivado en última instancia dun probable préstamo occitano (coitar) e non directamente do latín;

- cando (86) e garde (92) en lugar de cuando e guarde; 
- a representación explícita do seseo prenuclear en grasias (36), mais recoñecendo que a miña lectura desta palabra non coincide coas de Martínez Barbeito e Xosé María Álvarez Blázquez;

- bó (92) (< BŎNU) e non bon, en consonancia co que tamén se observa nas obras do cura de Fruíme;

- -án (san, 92) e -ás (màs, 66) ${ }^{16}$ como resultados das terminacións latinas -ĀNU e -ĀNŌS, respectivamente, coa excepción do substantivo grao (83), como xa vemos na primeira Tertulia en la Quintana (1820) e na actual lingua oral da bisbarra de Compostela (cf. Dubert García 1999: 84);

- pronome suxeito $t i(8)$ e non $t u$;

- demostrativos invariables con /'e/: nesto (90);

- adverbios de lugar absolutos terminados en -ó en alternancia cos acabados en -á e en -í, coma en diversas tertulias compostelás da época pregaleguista; o valor semántico dos dous da serie en -ó e do único testemuño dos acabados en -í é sempre translocal, mentres que o dos da serie en -á pode ser translocal ou situacional: Seique hè por que aló non vòlva (9), Virás acò (85), Ahí vay esa esmoliña (69), dou ò Demo pè ala poño (15) e ir alá (54), sen esquecer o adverbio contido na expresión alabay (88).

Tamén oubilo (79) se podería considerar como solución tomada do galego usado na comarca compostelá ao final do século XVIII, xa que modernamente o ALGa 1 (mapa 308), aínda que amosa ouvir como variante fundamentalmente meridional, sinala o emprego de ouvir e de oír en Xanceda (Mesía), é dicir, a só unhas decenas de quilómetros de Santiago en dirección nordeste.

Sabor popular, mais non localización diatópica tan definida presentan outros trazos do galego empregado por María Francisca: a utilización do verbo falar cun suplemento rexido pola preposición en (non falemos nesto mais, 90), as expresións haber doito 'acostumar, adoitar'"17 (22) e dar de costas (53) 'morrer', o chamado -s adverbial de soi mentes (45, 80) e de boa mentes (71) (cf. Ferreiro 1995: 348), o adverbio de afirmación abo fèllas (35) coa súa sufixación expresiva, os conecto-

\footnotetext{
${ }^{16}$ No manuscrito este màs parece estar corrixindo un máns anterior. Ora ben, tamén máns se usaría daquela, coma hoxe, pola comarca de Compostela, probablemente polas zonas máis occidentais.

17 Así a glosou Sarmiento (1973: 268) en 1745: “Doito. Costumbre, uso, hábito: non aven doito, non ha doito, etc., no está ejercitado, etc.”.
} 
res adversativos si ca si ${ }^{18}(62)$ e escom'asi ${ }^{19}(31)$-que en última instancia serán gramaticalizacións de así como así, con diversas contaminacións (cf. DCECH)-, etc. Inspirado na oralidade popular da época estaría tamén o uso do futuro de subxuntivo (fordes, 18; milloràr, 86), mais convén reparar en que o manuscrito pon en evidencia que no caso de coma si fordes rapàz (18), onde a orientación temporal non é prospectiva, o copista vacilou entre o emprego de fordes e o do pretérito forades, co que sen dúbida xa competía para a expresión dese valor modotemporal. De feito, naquela época o futuro de subxuntivo xa competía tamén co presente de subxuntivo en oracións temporais de orientación prospectiva introducidas por cando, como pon en evidencia a carta anónima de 1788 recentemente editada e estudada por Álvarez / Xove (2004: 53-54): "y-eses son os santos que te han de gardar quando morras".

A fidelidade á fonte popular e o baixo impacto da interferencia castelanizante amósanse nitidamente no terreo do léxico. Mantense sen substitucións o vocabulario nuclear en campos semánticos tales coma o das partes do corpo (sofràxes, 37; pestana, 63), as doenzas e padecementos (calafrios, 41; quentura, 42; mal catibo, 43; dores, 55; fremas, 84), os días da semana (cortafeira, 59) e os sentimentos, actitudes, sensacións e accións máis elementais (catar co sentido de "mirar con reflexión" que lle anotara Sarmiento (1973: 269) en 1745, 3, 22; aloumiñar, 8; enteimàr, 20; dòce, 21; encabujarse, 28; layarse, 34; agarimo, 46; enturrar, 65; empregar, 70; esbarroufar, 88; vafexàr, 96). Podemos dicir o mesmo do adverbio ou adxectivo sò $(75,91)$, que o Padre Sarmiento anotara e utilizara uns anos antes ca María Francisca de Isla (cf. Sarmiento 1970: 434; 1995: verso 68.4). No terreo do léxico relixioso o manuscrito deixa ver como a ameaza do castelanismo substitutorio é esconxurada pola autora do poema ou polo seu copista nos casos de Deus $(36,45,66,92)$ e esmoliña (69), que semellan corrixir os usos subxacentes de Dios e con toda a certeza corrixen o de limosna; non pasa o mesmo, en troques, no caso de Dios (44). Advírtese, por tanto, unha notable actitude purista fronte á interferencia lexical da lingua dominante, que con todo non foi abonda para desterrar nin Dios (44) nin viuda (73).

Préstamo aditivo e non substitutivo é desde logo tabaque (81), pois ben se sabe que a planta que así se designa e mais o hábito de fumala se tomaron de América a partir de finais do século XV: segundo Corominas e Pascual, a vacilación entre tabaco e tabaque, que xa se observa nas fontes castelás do XVI, explícase mellor se á palabra (non á planta) se lle atribúe unha orixe arábiga e non americana (cf.

18 Ao uso que neste verso fai del a Musa Compostelá acáelle perfectamente a seguinte glosa de Sobreira redactada contra o final do setecentos: “ASI CÁ Sí. Adv. de Ribadavia. Asi coma si, Escási, Sicási. Así como. Cast. En por eso, eso no obstante, con todo eso" (Sobreira 1979: 281)".

19 Saco Arce (1868: 135) caracterízaa como conxunción adversativa e dálle o seguinte valor: "Ecomasí, ecomadasí, siasí, á pesar de todo". 
DCECH). Grima (91), finalmente, semella un xermanismo tardío que entraría no galego a través do castelán.

Castelanizante ou non, coido que a maior parte do material lingüístico que fun debullando nesta sección deste artigo a tomou a Perla Galega da lingua galega oral do seu tempo. Claramente libresco -e tamén castelanizante- me parece en troques o seu uso de farto como cuantificador referido ao substantivo mal:

\author{
Deixame estàr à meu cabo \\ layandome do meu mal, \\ que abo fèllas farto teño; \\ grasias aDeus, que mo dà! (33-36).
}

Descoñécese este uso no galego e no portugués medievais, e desde logo tampouco se desenvolveu nestes idiomas posteriormente, quitando ocasionais interferencias coma esta de Isla y Losada. Segundo o DCECH, o primeiro emprego adverbial de harto en castelán data do século XVI, e para o XVIII podemos dicir que o Dicionario de Autoridades dá testemuño da súa utilización como cuantificador ilustrándoa cun exemplo tirado dunha obra de Santa Teresa de Jesús: "Y hartas veces no sé qué penitencia grave se me pusiera delante, que no la acometiera" (RAE 1726-1739: II, s.v.). A meu ver, o uso de harto como cuantificador debeu de lle chegar a María Francisca a través das súas lecturas; a partir delas, mediante un simple calco, pasaría a poeta santiaguesa a empregar o farto galego tamén como cuantificador. 


\section{Apéndice}

Manuscrito 9-3894, no 35 da Real Academia da Historia (Madrid)

Transcrición da copia parcial da Cantiga de Santa María número 256 do códice E 
Ramón Mariño Paz

Revista de a filoloxía

$* 2$.

ésa moller a Reura

Dona. Dexocis manera. que forre moxax enconca e' quant ela for acolá Luen ravingen gxoxcor a the. Na orre: è sel mandaro for ela mai volbonter é canso for na cidace peox enfexma molles, now vrstes doquefory ela cápeno de lompeller bonos frsicos, y' exan Dizian nox vwera. quen tha

éponque esto aczian non exa mery ron rason. ca d'avex eia sen fillo ertaba en á fazon éava tangian fevex. que, quen a' via enton Dizia repuxamente desta non escapana. duen ord

$\overline{92}$ 
$<1 \mathrm{a}>$

éssa moller á Reina

Dona Beatriz mandou

que fosse morar enConca

é quant elá foy acolá

Quen na Virgen groriosa etc

Na oste: è seu mandado

fez ela mui volonter

é cando foi na cidade

peor enferma moller,

non vistes doquefoy ela

cá pero de Monpeller

bonos Fisicos, ý eran

dizian non vivera

Quen etc

é porque esto dizian

non era muy sen razon

ca d' aver ela seu fillo

estaba en á sazon

é avia tan gran fever

que, quen á via enton

dizia seguramente

desta non escapara

Quen etc 
Ramón Mariño Paz

Revista de a filoloxía

Nois la he y na quesexura exaloa que pooe é vale vixgen anta qloxiora. Reuna Espisciolal fer twager hura omagen muy ben feita demeral zelante chancia ryfe esta cato me sexall Luen nationgen tre.

caposen a fla sequxa vir atal exceencial oi queretorof estes maes que ation torie guancei: pox eno a mi a chey e loop lle beif axei? asisarmang e opfees camuy quan frolonezexiá Iuentio

étod ese arifor ter to elogever oububen Detrotiaqueles maes quancie a keyria tanben serpoder a a floxirad. quenadanbuventu en poken sexaizemalozso o que a nox loana: Iuen rownoeng bouse.

$\overline{94}$ 
$<1 \mathrm{~b}>$

Mais la Reyna que serva

era da que pode é val

Virgen Santa gloriosa.

Reyna Esperital ${ }^{20}$

fez trager huna omagen

muy ben feita de metal

desanta Maria disse

esta cabo mi será.

Quen naVirgen etc

ca pois eu à ssa segura ${ }^{21}$

vir atal creencia ei

que de todos estes maes

que atan toste guarrei:

por end à mi a chegade

e logo lle beijarei

as sas manos é os pees

ca muy gran prol meterrá

Quen etc

étod'est'assi foy feyto

e logo sen outro ven ${ }^{22}$

detod $^{\mathrm{s}}$ aqueles maes

guariu a Reyna tanben

per poder da gloriosa

que nada nonsentiu en

poren sera demal siso

ô que a non loará.

Quen naVirgen gloriosa

20 Talvez Espirital.

21 Lectura errada por fegura.

${ }^{22}$ Este ven semella corrixir un ben anterior. O transcritor non entendeu correctamente o orixinal, onde se di outra ren. 


\section{Bibliografía $^{23}$}

ALGa 1 = Instituto da Lingua Galega (1990): Atlas lingüístico galego. Vol. 1: Morfoloxía verbal. 2 vols. (A Coruña: Fundación Pedro Barrié de la Maza).

ALGa 3 = Instituto da Lingua Galega (1999): Atlas lingüístico galego. Vol. 3: Fonética (A Coruña: Fundación Pedro Barrié de la Maza).

Álvarez Blázquez, X. M. (1959): Escolma de poesía galega. II. A poesía dos séculos XIV a XIX (1354-1830) (Vigo: Galaxia).

Álvarez, R. / Xove, X. (2002): Gramática da lingua galega (Vigo: Galaxia).

Álvarez, R. / Xove, X. (2004): "Achegas para a historia da lingua: unha carta do século XVIII", en Álvarez, R. / Santamarina, A (eds.), (Dis)cursos da escrita. Estudos de filoloxía galega ofrecidos en memoria de Fernando R. Tato Plaza: 35-64 (A Coruña: Fundación Pedro Barrié de la Maza).

Carballo Calero, R. (1979) [1966]: Gramática elemental del gallego común (Vigo: Galaxia).

Cernadas y Castro, D. A. (1778-1781): Obras en prosa y verso del Cura de Fruime D. Diego Antonio Cernadas y Castro, natural de Santiago de Galicia. 7 tomos (Madrid: Joachin Ibarra).

DCECH = Corominas, J. / Pascual, J. A. (1987/1989/1991): Diccionario crítico etimológico castellano e hispano. 6 vols [vol. 1: 1987; vols. 2, 3, 4: 1989; vols. 5, 6: 1991] (Madrid: Gredos).

Dubert García, F. (1999): Aspectos do galego de Santiago de Compostela. Anexo 44 de Verba (Anuario Galego de Filoloxía) (Santiago de Compostela: Universidade de Santiago de Compostela).

Ferreiro, M. (1995): Gramática histórica galega (Santiago de Compostela: Laiovento).

Filgueira Valverde, X. (1984): Terceiro Adral (Sada / A Coruña: Ediciós do Castro).

García Cortés, C. (2002): O Cura de Fruíme Diego Antonio Cernadas e Castro (17021777). Recuperación biográfica. Catalogación da obra publicada. Antoloxía poética galega (Santiago de Compostela: Instituto Teolóxico Compostelano).

Isla, J. F. de (1850): Obras escogidas, con una noticia de su vida y escritos, por don Pedro Felipe Monlau (Madrid: Imprenta de la Publicidad).

Lorenzo, R. (ed.) (1975-1977): La traducción gallega de la Crónica General y de la Crónica de Castilla. Edición crítica anotada, con introducción, índice onomástico y glosario. 2 vols. (Ourense: Instituto de Estudios Orensanos Padre Feijoo).

${ }^{23}$ Extraín datos dos seguintes dous tesouros informatizados [setembro 2005-febreiro 2006]: 1) TILG: Antón Santamarina (dir.) (2003): Tesouro Informatizado da Lingua Galega (Santiago de Compostela: Instituto da Lingua Galega) (http://www.ti.usc.es/TILG/); e 2) TMILG: Xavier Varela Barreiro (dir.) (2004): Tesouro Medieval Informatizado da Lingua Galega (Santiago de Compostela: Instituto da Lingua Galega) (http://corpus.cirp.es/tmilg/). 
Mariño Paz, R. (1995): "Estudio introductorio", en Fr. M. Sarmiento, Coloquio de vintecatro galegos rústicos. Edición de Ramón Mariño Paz: 7-102 (Santiago de Compostela: Consello da Cultura Galega).

Mariño Paz, R. (1999) [1998]: Historia da lingua galega (Santiago de Compostela: Sotelo Blanco).

Mariño Paz, R. (2000): “As liñas en galego do Theatro Moral y Político de la Noble Academia Compostelana (1731) de Pablo Mendoza de los Ríos", Revista Galega de Filoloxía, 1: 35-65.

Mariño Paz, R. (2003): O idioma galego no limiar da súa renacenza. Estudo lingüístico de textos pregaleguistas. Monografía 2 da Revista Galega de Filoloxía (A Coruña: Áreas de Filoloxías Galega e Portuguesa da Universidade da Coruña).

Martínez Barbeito, C. (1958): "Doña María Francisca de Isla y su romance en gallego al cura de Fruíme", Boletín de la Real Academia Gallega, 28: 17-36.

Mettmann, W. (ed.) (1959-1972): Alfonso X, Cantigas de Santa Maria. 4 vols. (Coimbra: Acta Universitatis Conimbrigensis).

Monlau, P. F. (1850): "Noticia de la vida y obras del Padre Isla", en J. F. de Isla: Obras escogidas, con una noticia de su vida y escritos, por don Pedro Felipe Monlau: I-XXXVII (Madrid: Imprenta de la Publicidad).

Pensado, X. L. (ed.) (1995): Traducción de algunas voces, frases y locuciones gallegas, especialmente de agricultura, al castellano (1840-1858). Anexo 2 de Cadernos de Lingua (A Coruña: Real Academia Galega).

RAE (1726-1739): Real Academia Española (1726-1739): Diccionario de la lengua castellana, 6 vols: vol. 1: Madrid: Francisco del Hierro, 1726; vol. 2: Madrid: Francisco del Hierro, 1729; vol. 3: Madrid: Viuda de Francisco del Hierro, 1732; vol. 4: Madrid: Herederos de Francisco del Hierro, 1734; vol. 5: Madrid: Herederos de Francisco del Hierro, 1737; vol. 6: Madrid: Herederos de Francisco del Hierro, 1739. Ed. facsímil: Diccionario de Autoridades. 3 vols. Madrid: Gredos, 1990.

RAE (1779): Real Academia Española (1779) [1741]: Ortografia de la lengua castellana (Madrid: Joachîn Ibarra).

Rodríguez Elías, A. (1930): Obras teatrales galegas (Vigo: Faro de Vigo).

Saco Arce, J. A. (1868): Gramática gallega (Lugo: Soto Freire).

Sarmiento, Fr. M. (1970): Colección de voces y frases gallegas. Edición y estudio por J. L. Pensado (Salamanca: Universidad de Salamanca).

Sarmiento, Fr. M. (1973): Catálogo de voces y frases de la lengua gallega. Edición y estudio por J. L. Pensado (Salamanca: Universidad de Salamanca).

Sarmiento, Fr. M. (1995): Coloquio de vintecatro galegos rústicos. Edición de Ramón Mariño Paz (Santiago de Compostela: Consello da Cultura Galega).

Serrano y Sanz, M. (1903): Apuntes para una biblioteca de escritoras españolas desde el año 1401 al 1833. 2 vols. (Madrid: Establecimiento Tipográfico "Sucesores de Rivadeneyra"). 
Sobreira, Fr. J. (1979): Papeletas de un diccionario gallego. Ms. s. XVIII. Edición y estudio crítico por J. L. Pensado (Ourense: Instituto de Estudios Orensanos "Padre Feijóo").

Valladares, M. (1970) [escrita en 1892]: Elementos de gramática gallega (Vigo: Galaxia). 023 